\title{
PRE-SEQUENCES AND SPEECH ACTS IN CEBUANO RADIO HEALTH COMMERCIALS IN CEBU CITY
}

\author{
Ceska Marie R. Apalla, Keeshia Joy S. San Juan ${ }^{2,}$ and Rowanne Marie R. Maxilom ${ }^{3}$ \\ University of San Carlos, Philippines \\ skylinglit@gmail.com ${ }^{1}$,keeshia018@gmail.com ${ }^{2}$, rmmaxilom@gmail.com $^{3}$
}

\begin{abstract}
This research attempted to identify and analyze the Cebuano-Bisaya radio health commercials using Schegloff's (2007) framework on pre-sequences with the support of Yule's (1996) speech act theory. Thirty (30) Cebuano-Bisaya radio health commercials were gathered from two selected radio stations. The results revealed that representatives were the most dominant function in speech acts that reflected in pre-sequences specifically with pre-offers and pre-announcements through drama and testimonial categories which are often used in medicinal product commercials. In advertising strategies, Cebuano-Bisaya commercials use Representatives and Expressive as persuasive devices in addressing the advertisers' intended message to the target audience. Also, Cebuano-Bisaya commercials used Representatives and Expressive as an appeal to suggest an intention for the listener to buy advertised products.
\end{abstract}

Keywords: Cebuano, commercial, health, pre-sequences, radio, speech acts

\begin{abstract}
Abstrak
Penelitian ini bertujuan untuk mengidentifikasi dan menganalisis iklan komersial kesehatan di radio menggunakan teorinya Schegloff's (2007) dengan kerangka berpikir pada pra-tahapan dan teorinya Yule (1996) tentang tindak tutur. Tiga puluh iklan kesehatan dari dua radio yang ada Cebuano-Bisaya dipilih untuk untuk penelitian ini. Hasil penelitian ini menunjukkan bahwa representasi adalah yang paling dominan dalam tindak tutur yang terefleksi dalam pratahapan khususnya dengan pra-tawaran dan pra-pengumuman melalui drama dan kategori kesaksian yang sering digunakan dalam iklan produk medis. Dalam strategi periklanan, iklan Cebuano-Bisaya menggunakan represetasi dan ekspresi sebagai alat untuk menunjukkan apa pesan yang dimaksud oleh pengiklan kepada target. Cebuano-Bisaya juga menggunakan representasi and ekspresi sebagai seruan yang menyarankan pada pendengar untuk membeli barang yang diiklankan.
\end{abstract}

Kata Kunci: Cebuano, iklan, kesehatan, pra-tahapan, radio, tindak tutur

\section{Introduction}

Because many people are getting conscious of their wellness and vitality, there have been so many radio commercials nowadays related to health. In fact, “... people have become more conscious with their health" stated by Saban $(2013, \mathrm{p} .1)$, the publisher of 100 health conscious info graphics. This trend had reached different places around the world and has gone into different forms of media wherein commercials are aired on TV, radio stations and even published through online social networks, and print ads such as magazines, 
newspapers, tarpaulins and leaflets. These advertisements have greatly influenced the consumers' preference on purchasing products, an idea evident in the study of Tejal, et al. (2013) on cosmetics. Part of this present study, on radio commercials, focused on the art of commercial which contributed to business. As an art, a commercial "should not only be visually appealing but also linguistically" (Guga-Cotea, 2013, p.261) captivating because its purpose is to persuade and to sell goods, services, ideas (Guga-Cotea, 2013) through "celebrity endorsement, romantic imagery, gender identity or ways of attaining happiness and comfort" (Guga-Cotea, 2013, p.261).

The study on commercial is interesting because it "is concerned not only with language but also with the context of communication" (Cook, 2001 in Guga-Cotea, 2013 p.261). Moreover, the study on commercials also considers the audience's personalities, cultures and social positions because commercials should be addressed through the target audience's language and needs. With the interest on commercials, Guga-Cotea (2013, p.261) specified that advertising through commercials is a form of communication which means that language is part of the effective business strategy for persuading the audience. As for effective advertising, "discourse strategies" (Fuertes-Olivera, et. al, 2005, p.1295 in Dayag, 2008) or "persuasive devices" (Martinez, 2005, p.85 in Dayag, 2008) were used as evident in Dayag's (2008) study on print advertisements. Part of Dayag's (2008) study was on speech acts which were elaborated on the predominant classification of speech acts presented in Philippine health and entertainment magazines published from 2005 to 2007. On the other hand, instead of magazines, Ariosa (2011) studied Searle as cited in Ariosa, 2011) speech acts theory on 100 green advertisements of Cebu's local newspapers namely as Cebu Daily News, Sun Star and The Freeman.

The present researchers have observed that broadcast media, specifically on radio stations, with the present studies in commercials, were less studied by researchers in the Philippines which made this study a need because the theory on speech acts was usually applied on print media while pre-sequence was barely introduced and studied in any forms of media or conversation analysis in the Philippines. For that reason, this study focused on radio which aimed to identify the categories of radio commercials (Warner, 2009) which were frequently aired in Cebuano radio stations. Afterwards, these frequently aired categories are analyzed and clustered through Yule's (1996) general functions of speech acts.

Moreover, this study did not only focus on the communicative force, speech acts, but also on pre-sequence which was according to Levinson (1983) it is a specific turn that has the function of anticipating the conversational action. Since this study was on commercials, the addressee's cooperation was already anticipated. By knowing the audience, a communicative force was used to make conversational action to the listener. The present study was similar to Bernsten's (2002) study on pre-sequences. However, the language used in the present study was based on mother-tongue instead of English which Bernsten (2002) used in his study on "Using conversation analysis to evaluate pre-sequences in invitation, offer and request dialogues in ESL textbooks." The present study further explored the assumption between the relationship of speech acts and pre-sequences which was proven through the conducted study.

Mass media have been very convenient in promoting health awareness in televisions, radios, newspapers, pamphlets, magazines, and billboards (Robertsion, et al. 1974 in Ray $\&$ Donohew, 1990). Moreover, as part of the broadcasting media, television and radio have been both influential to a wider range of audience since they offer easier access to rural and urban areas. In fact, according to Thompson and Yeboah (2013), Ghanaians prefer radio and television as their chosen media since $49 \%$ of the population cannot read and write which 
is similar to the conducted survey by the Philippine National Statistics office on Filipino households in 2008 wherein one out of ten Filipinos is illiterate and this ratio is highest in the National Capital Region and lowest in the Autonomous Region for Muslim Mindanao. With these provided media platforms, the audience was more able to understand the information given because these two media are able to speak the language which are very helpful in providing a health-literate populace (Thompson \& Yeboah, 2013).

In a similar concern on media, Philippines, as one of the project countries of KonradAdenauer-Stiftung (KAS) which is a German political foundation that has been publishing Democracy Reports since 2005, released a report in 2008 focusing on media and media system. In partnership with Philippine National Statistics Office, a survey was regulated on Philippine households which resulted to $81.22 \%$ of the population owning a radio and $44.93 \%$ owning a television which meant that most of the population had easier access to radios. However, three main sources of information and entertainment were found in KAS democracy report $(2008$, p.83) in the capital city, Manila, which were "1) television, 2) newspapers, and 3) radio". However, compared to the places outside the capital city, radio ranked second as the most consumed media.

Furthermore, as part of the prominent forms of media, a radio listenership was conducted in two of the biggest cities in the Philippines, Manila and Cebu, by the Kapisanan ng mga Broadkaster ng Pilipinas, KBP, (2004 in KAS Democracy report, 2008) wherein most radio listeners consume at least ten hours a week and on average, spend 20 hours a week for music and entertainment (KBP, 2004 in KAS Democracy Report, 2008). However, survey revealed that there were specific times of the day when more media consumers listened to radio and more viewers watched TV. In a day, 5 a.m. to 10 a.m. and from 3 p.m. to 5 p.m. were the hours when there were more radio listeners than there were TV viewers (KBP, 2004 in KAS Democracy Report, 2008). On the other hand, evening time slots from 6 p.m. to 10 p.m. were the hours when television was the most consumed media by the Filipinos (KBP, 2004 in KAS Democracy Report, 2008). Radio, as one of the leading forms of media, does not only provide entertainment but is also used as an information tool to disseminate awareness specifically about health among radio listeners. This health propaganda can be spread through radio commercials which can inform the audience about the health benefits and consequences of what Dayag (2008) labels as consumer non-durables which include medicines/food supplements, cosmetic/beauty/personal hygiene products and household products.

Medicines are divided into “...six main categories: analgesics, blood tonics, cough preparations, antimalarials, worm expellers and laxatives" (Erhun \& Erhun, 2002, p.4). Based on Erhun \& Erhun's (2002) study on the impact of broadcast media commercials on the perception on medicines, Analgesics was found to be the most recalled category in Nigeria because of being frequently aired in the broadcast media. On the other hand, worm expellers are the least remembered category by the listeners yet has the highest percentage on awareness among listeners. Aside from medicines, cosmetic, beauty, personal hygiene products are also considered as part of the agenda in disseminating health awareness and these products include "... makeup like mascara, eye shadow and eyeliners; facial cleansing systems, including cleanser, toner and moisturizer; nail polish and also lotions, lipsticks, skincare products, powders" (Tejal, et al. 2013, p.392) and also shampoo because “... cosmetics contain chemical component which directly or indirectly can cause adverse effect on human" (Tejal, et al. 2013, p.396).

Furthermore, household products are also advertised to raise the level of health awareness through broadcast media advertisements and these include "...liquid detergent capsules... 
bleaches... air fresheners... multipurpose cleaners... dishwasher products and descalers" (Williams, et al. 2012, p.770). The products with their health benefits and consequences, under Dayag's (2008) consumer nondurables, have easily reached the audience because of the great influence caused by commercials which are both evident in Erhun \& Erhun's (2002) and Thompson \& Yeboah's (2013) studies on the impact of broadcast media to the audience. However, to entice a particular audience, language is the most needed instrument to transmit the message which is crucial in radio commercials. According to Schmidt \& Kess (n.d), language is important but to understand its wider role in the persuasion process is crucial because it is based on the context and the spoken-language used by the audience. Therefore, to understand commercials, particularly in radio, their discourse strategies and persuasive devices are considered.

\subsection{Radio Commercial}

Part of the persuasive devices used in radio commercials are the means of convincing the audience since radio commercials cannot rely on images. This creative persuasion process is based on the language and the speaker (Vilariño, 1996, p.196). According to Warner (2009), commercials can be presented through five radio commercial categories: jingles, testimonials, drama/dramatization, humor and straight forward information. As to the first category, jingle is defined as a commercial that is delivered through a song (Warner, 2009) and like visual techniques, it is used as a tool to attract audience attention as means to aid recall (Magsaysay,1984) . In a similar way, Gupta (2013) defined jingle as a very useful tool in recalling and promoting products which was also found by Allan (2006) in his study that popular music is also effective in calling attention because of the recalling strategy.

The second category is Testimonial which is a marketing-communication tool because it persuades listeners through actual evaluations of the first-hand users (Shimp, Wood \& Smarendescu, 2009) and their personal experiences. Also, testimonials consist of the personal information of the person such as the name, age, address and the reasons on how the product has helped him or her. The third category is the Drama/dramatization which is a category which consists of storytelling about the product. However, the so-called drama is not about the dramatic way of delivering the information, but instead it is "a slice-of-life story."

Fourth is the Humor which is a category that makes use of jokes in advertisement (Harris, 2009, in Warner, 2009). However, this has been criticized by many researchers since it is very risky, especially with the kind of product being introduced to the audience, but Olsson \& Larsson (2005) stated that humor attracts the attention of the listeners and can help recall the product for a longer period of time which is also supported by McLeish (1994) with his statement that "the listener will enjoy the new jokes as as welcoming old favoritesfurther, he will recall the product long before the ad gets to it." In contrast, the impression of the product is at stake since its credibility will be questioned but several considerations will be recognized as emphasized by Sliburyte \& Klimavicius (2012) since there are chosen products that can be appropriate and effective in some situations.

The fifth and last category is the straightforward information which is defined as the basic message of the commercial wherein the purpose is directly stated (Magsaysay, 1984). Also, it is a category wherein commercials enlist information and facts about a product however it is rarely used due to lack of creativity with persuasion strategy (Warner, 2009). An Example would be from Ciccarelli (n.d) which compared to the previous categories, straightforward information directly announces and informs the listeners with their basic information and details which makes this category short. 
The power of persuasion cannot be achieved without the power of language (Vilariño, 1996) therefore, in order to attain its means of relating and enticing listeners, linguistic communicative means through pragmatics specifically on pre-sequences and on speech acts were considered. Pragmatics is essential to radio commercials because communication from both perspectives - advertising and pragmatics, consider the contextual dimension of a language. Also, it is closely related to discourse analysis because pragmatics " draws on natural language data to develop generalizations concerning linguistic behavior, whereas discourse analysis draws on these generalizations in order to more closely investigate natural language" (Birner, 2013). Therefore, through discourse and pragmatics, the hearer is able to interpret the speaker's intended intention in a specific context. In relation to radio commercials, the intention of the advertiser is very much important because advertisers must know how to address their intentions in a specific context of the target audience.

\subsection{Pre-Sequences}

In order to achieve the goals of an advertiser, it is important to call one's attention before introducing the product which is the foremost process in persuasion and this is called Pre-sequences (Schegloff, 2007). Pre-sequence is also known as first pair part (FPP), base pair of adjacency pair (AP) in sequence organization (Schegloff, 2007) and "sequence- initial items" (Lerner, 2004). According to Schegloff (2007), there are two kinds of pre-sequences: (1) the type-specific pre-sequences which is often used and found in most pre-sequences since it is "designed to lead to some particular kind of base sequence", and (2) the generic pre-sequence, also known as summon-answer sequence, which is used in any form of a following talk and is intended to gain a recipient's attention as stated by Liddicoat (2007) and Schegloff (2007). However, Sidnell (2010) stated that type-specific and generic presequences belong to pre-expansion. Nevertheless, the term pre-sequences in this study will be based on Schegloff's (2007) type-specific pre-sequences which will be used to interpret and analyze the data because these kinds of pre-sequences do not require a response from the hearer.

Specific type of pre-sequences can be addressed in four different types:

(i) Pre-invitation is a pre-sequence that often checks the availability of an invitee (e.g. Hey, want to go to my birthday party?). (ii) Pre-offer is a pre-sequence that often checks the availability of the item or situation to be offered for. (e.g. Do you want to borrow my pencil?). (iii) Pre-announcement, also known as story-preface, is a presequence that the recipient does not know the thing to be told or announced (iii) Do you know who's going to the meeting? (iv) Pre-pre is a pre-sequence that projects a further pre-sequence that typically checks whether a recipient will be able to recognize some person, place, or thing to be talked about (Schegloff 1988, 2007, Levinson 1983, Terasaki 2004 [1976] in Sidnell 2010). (e.g. I like to ask you something.)

\subsection{Speech Acts}

Guga-Cotea (2013) explains that the "significance of language emphasizes the communicative function of language as a social activity". Therefore, through speech acts, language as an activity is only successful if there is a common understanding between individuals involved in the process of communication. According to Austin (1962 in GugaCotea, 2013) and Searle (1969 in Guga-Cotea, 2013), who had great influence on the development on the Speech Act theory, mutual understanding between interlocutors is based 
on how the listener interprets the intended utterance of the speaker. Thus, when producing utterances, three related acts will be performed:

(1) locutionary which is the utterance and the meaning itself, (2) illocutionary which refers to the goal, purpose of its utterance and communicative force, and (3) perlocutionary which makes reference to the effect produced on the audience through locution and illocution.

Related to the present study, the necessary act that is best applicable for commercials is also the illocutionary because it focuses on the communicative force of an utterance which is the primary goal of radio commercials.

Furthermore, functions, that this study uses, are considered as generally performed by the speech acts and these were the following:

First, declarations are acts that change the world through their utterances such as sentence, pronounce, curse, name etc. (e.g. "Priest: I know pronounce you husband and wife"). In declarations, the context and the role allow the speaker to perform his declarations (Yule, 1996 in Guga-Cotea, 2013, 262). Second, representatives are acts that are used to describe what the speaker believes true or not such as describe, insist, predict, and claim. (e.g. "The earth is flat"). The speaker represents the world as he/she believes it (Yule, 1996 in Guga-Cotea, 2013, 262). Third, commissives are acts that commit the speaker to a future action such as promise, offer, refuse, and threat.

(e.g. "I'll be back"). The speaker expresses what he/she intends to do (Yule (1996 in Guga-Cotea, 2013, 262). Fourth, expressives are acts that state what the speaker feels such as statements of pleasure, joy, sorrow, like and dislikes (e.g. "I am so happy"). The speaker expresses his/her psychological state (Yule, 1996 in Guga-Cotea, 2013, 262). Finally, directives are acts that are used by the speaker in order to make the hearer do something" such as order, command, invite and suggest (e.g. “Don't you dare open the door"). The speaker expresses that he/she doesn't want the hearer to do. (Yule, 1996 in Guga-Cotea, 2013, 263).

In advertising, to inform, to persuade, to convince, to invite, and to make the consumers believe are the general objectives of commercials which are the general functions performed by speech acts. Thus, through speech acts, advertisers could know their effectiveness and achieve their illocutionary goals by how they address and introduce a product to their target audience. In Guga-Cotea's (2013) study on twenty-five (25) English advertisements, which was based on Yule's (1996) framework on speech acts, it resulted to 126 speech acts and as she expected, expressions and declarations were not used because these functions were found inappropriate for advertising.

On the other hand, as expected by Guga-Cotea (2013), directives and commissives were frequently used in print advertisements compared to representatives because these advertisements can directly, explicitly and efficiently communicate ideas and messages in the English advertisements. In a similar way, Ariosa (2011) conducted a study on the local print media in Cebu specifically on Cebu Daily News, SunStar, and The Freeman. Similar functions of speech acts were found: directives and representatives. However, compared to Guga-Cotea's (2013) study, representatives were frequently used in local print media in Cebu compared to directives which were "found embedded in the imperatives" (Ariosa, 2011).

In this present study, the researchers aimed to analyze Cebuano-Bisaya radio health commercials since radio-commercials were barely studied in the local linguistic society. Moreover, observations and related studies have encouraged the researchers to investigate 
the radio commercials using the frameworks of Schegloff's (2007) pre-sequences and Yule's (1996) functions of Speech Acts.

The purpose of this study was to identify and analyze the health products through Cebuano-Bisaya radio commercials aired in Cebu using Schegloff's (2007) framework on pre-sequences with the support of Yule's (1996) speech act theory.

Specifically, this study aimed to answer the following questions: (i) Which categories of radio commercials of Warner (2009) were frequently used in Cebuano radio stations?

(ii) Which of these type-specific pre-sequences proposed by Schegloff (2007) were used in these health products? and (iii) What are the patterns reflected in Schegloff's (2007) typespecific pre-sequences and Yule's (1996) functions of speech acts.

\section{Methodology}

This study used a quantitative-qualitative method of research which used Warner's (2009) categories of radio commercials. It also anchored on Yule's (1996) general functions of speech acts and Schegloff's (2007) type-specific pre-sequences in categorizing and analyzing Cebuano radio health commercials covering a three-month period from September 2014 to November 2014. For quantitative method, Cebuano health commercials from radio stations were identified, coded and tabulated. On the other hand, qualitative method was used to analyze the patterns in terms of relationship between the general functions of speech acts and type-specific pre-sequences which will further understand the purpose of using different categories of commercials in radio stations. It was also used to analyze the effectiveness of commercials in radio stations.

This study used both purposive and convenient sampling since the source was based on Cebu's top two radio stations during the $2^{\text {nd }}$ quarter of Nielsen Radio Audience Measurement (2014). It was a purposive sampling because the criteria for choosing the radio stations were based on the Nielsen Radio Audience Measurement (2014). It also utilized the convenient sampling because the study was limited to two radio stations only. The researchers decided to take one radio station each for individual recording.

From the two radio stations, the researchers recorded radio health commercials that were aired on September 2014 to November of 2014.

The commercials were based on the criteria set by the researchers: (1) commercials should be aired from 15 seconds to 60 seconds or so within the specific hours- from six o'clock in the morning until twelve o'clock at midnight in both radio stations. It was indicated from the questionnaire among the radio stations, answered by the radio station representatives, that the earliest peak hour of the top two radio stations was at six o'clock in the morning and the latest was at twelve o'clock at midnight;(2) it should be about health which Dayag (2008) labeled as "consumers non-durable"- medicines/food supplements, cosmetics/beauty/personal hygiene products and household products since it will be based on one of the university's agenda which belonged to the theme of Food/Health awareness; (3) the spoken language used in airing the products was Cebuano-Bisaya since the target listeners were the mass audience in most urban and some rural areas of Cebu which also spoke and/or understood Cebuano-Bisaya language but code-switch was also considered, and lastly, (4) it should be aired among the radio stations located within the premise of Cebu.

The recorded three-month-period Cebuano radio health commercials served as the main instrument of the researchers. Each commercial was utilized for categories of radio commercials. Moreover, these commercials were used to determine and to analyze patterns in terms of relationship between general functions of speech acts and type-specific presequences in relation to "discourse strategies" (Fuertes-Olivera, et al. 2005, p.1295 in Dayag, 
2008) or "persuasive devices" (Martinez, 2005, p.85 in Dayag, 2008) in advertising. With regard to radio stations, a questionnaire was handed which was answered by a representative of each radio stations. An interview with the station managers were also conducted to validate more information of the data such as how they were able to gather the commercials and under what terms and conditions, with the clients, do they follow as per the timeslot of the aired commercials.

The Cebuano radio health commercials were recorded using Asus laptop and Starmobile B205 mobile phone. The products were then transcribed using Express Scribe Transcription Software, a professional audio player software for PC or Mac designed to assist the transcription of audio recordings such as determining the exact time of the conversation and adjusting the volume and speed of the time which was made by NCH software (http:// www.nch.com.au/scribe/index.html) and can be downloaded in the Internet.

The top two radio stations were given letters of consent which assured them that the gathered data were used for academic purposes only. Moreover, a questionnaire was handed, which was answered by a representative of the radio stations, to identify the following: (1) the name of the FM radio station, (2) its location, (3) the peak hours (4) the dominant language used during peak hours, (4) the length of the products advertised, (5) the number of the products accepted, and 6) the awards received from the year 2013 to 2014 . An interview with the station managers was also conducted to further know the following: (1) how many peak hours do they have in a day, (2) how many products do they air during peak hours, and (3) the terms and conditions agreed between the radio stations and clients.

The researchers collected fifteen (15) Cebuano health commercials from each radio stations with a total of thirty (30) which consisted of five (5) commercials on each labels of Dayag's (2008) "consumer non-durable" in medicines/food supplements, cosmetics/beauty/ personal hygiene products and household products. The commercials were picked through the first commercials that were heard by the researchers. The radio health commercials were transcribed then translated into English. However, the Cebuano-Bisaya language was used for the data analysis. To double check the data, a senior Linguistic Major student became the researcher's verifier as she already completed the undergraduate thesis which was about Cebuano utterances. Also, a faculty of the department of Linguistics and Literature in the university was asked to be the verifier of the English Gloss.

In order to answer the first sub-problem, the transcribed commercials were clustered according to Warner's (2009) categories of radio commercials which were either of the following: jingle, testimonial, drama, humor, or straightforward information. As for the second sub-problem, the dominant categories were utilized to cluster in Schegloff's (2007) type-specific pre-sequences which were specific turns that had functions of anticipating the conversational actions. Lastly, aside from identifying, the researchers aimed to relate the patterns reflected between the type-specific pre-sequences and Yule's (1996) general functions of speech acts which were communicative forces wherein the speaker intends for a reaction or participation from the hearer.

\section{Results and Discussion}

In this section, the categories of radio commercials, pre-sequences, and speech acts are presented.

Table 1 presents the results on the categories of the radio commercials reflected in the data. 
Categories of Radio advertisement

$\mathrm{N}=30$

\begin{tabular}{|c|c|c|c|c|}
\hline \multirow{2}{*}{$\begin{array}{l}\text { Categories of Radio } \\
\text { commercials }\end{array}$} & \multirow[b]{2}{*}{ RS1 } & \multicolumn{2}{|c|}{ f } & \multirow[t]{2}{*}{$\%$} \\
\hline & & RS2 & Total & \\
\hline Drama & 8 & 8 & 16 & $53.33 \%$ \\
\hline Testimonials & 1 & 5 & 6 & $20 \%$ \\
\hline Straightforward & 4 & 0 & 4 & $13.33 \%$ \\
\hline Jingles & 2 & 2 & 4 & $13.33 \%$ \\
\hline Humor & 0 & 0 & 0 & $0 \%$ \\
\hline TOTAL & 15 & 15 & 30 & 100 \\
\hline
\end{tabular}

Legend: RS1 - Radio Station 1

RS2- Radio Station 2

Drama has the highest frequency of occurrence with $53.33 \%$ followed by Testimonials with 20\%, Jingles and Straightforward information with $13.33 \%$. Unfortunately, humor did not occur in the radio commercials.

Drama ranks as the primary category present in Cebuano radio commercials because this category was relatable to the listeners through depicted life scenarios of the target audience. According to Book et al. (1996), one of the guidelines in radio advertising is to write conversationally which means the commercials should imitate the language and the language use of the target audience. This is the reason why drama was frequently utilized in Cebuano commercials because it was able to "visually and conceptually" (Book et al., 1996) deliver the message of the commercial to the listeners. Also, Pasu-it (interview, 2015) affirms that drama indeed is dominant in Cebuano commercials because it is creative and relatable especially to the target audience which is the low and middle classes. Moreover, it was observed that drama is the most prevalent category used for personal hygiene/cosmetic products since it depicts the general life scenarios of the target audience thus, fictional characters and scenes were used which are shown in the example below:

\section{Example 1: Drama}

PUS1 : Flash report

$(\mathrm{S} 2 \mathrm{C} 11 \mathrm{~L} 1)$

Lunch time na ug puno na kaayo anng canteen

(S2C11L2)

(It's already lunch time and the canteen is so occupied)

Naay dalagang mutapad sa lamisa ni Dennis

(There is a woman who will sit beside Dennis)

(S2C11L3)

Ni-a na

(S2C11L4)

(coming)

Paduol na siya

$(\mathrm{S} 2 \mathrm{C} 11 \mathrm{~L} 5)$

(she is becoming nearer)

PUS2: Ah..

Is this seat taken?

Based on Example 1, initially, the scenario was already presented through PUS1's narration in S2C11L2 and S2C11L3. In S2C11L2, a description about the place was made, however, no specific place was mentioned but a general name which most people could relate 
to, which is the canteen. Afterwards, a name was introduced by PUS1 in S2C11L3 which is the main character of the story. However, no specific name was introduced. A common name was relatable to the listeners because it could be their name or the listeners could have known of someone who had the same name. Moreover, based on example 1, a common place and a common name were used because the primary goal of drama is to depict a general scenario of the target audience which could be relatable to a bigger number of listeners.

\section{Example 2: Testimonial}

PUS1: Ako si Mark Havin, arkitekto.

$(\mathrm{S} 1 \mathrm{C} 1 \mathrm{~L} 1)$

(I am Mark Havin, architect.)

Kanunay gyud ko ganahan mutrabaho tungod sa MX3 capsule.

$(\mathrm{S} 1 \mathrm{C} 1 \mathrm{~L} 2)$

(I am always motivated to work because of MX3 capsule)

Naka MX3 kada adlaw adlaw, maong MXtraordinary.

(S1C1L3)

(I take MX3 everyday, that is why MXtraordinary.)

PUS2: No proof therapeutic claims.

In Example 2, PUS 1 directly stated his name and his profession in S1C1L1 "Ako si Mark Havin, arkitekto" to confirm that he was one of the product users who had experienced the benefits of the product. Through PUS1's personal information, the quality and the credibility of the product were intensified. In addition to the distinction between drama and testimonial, drama creates life-scenarios that can be addressed to the general population of the listeners while testimonials announce and state personal information as a technique for enticement which captures less number of listeners from the target audience because a specific person such as "Mark Havin ... (S1C1L1) and specific profession such as "... arkitekto (S1C1L1)" could only be relatable to a fewer number of listeners from the target audience.

Table 2 shows the type-specific pre-sequences found in Cebuano radio health commercials.

Table 2

Type-Specific Pre-Sequences

$\mathrm{N}=23$

\begin{tabular}{ccc}
\hline Type-Specific Pre-Sequences & F & \% \\
\hline Pre-offers & 10 & $50 \%$ \\
Pre-announcements & 5 & $25 \%$ \\
Pre-pres & 3 & $15 \%$ \\
Pre-invitations & 2 & $10 \%$ \\
TOTAL & $\mathbf{2 0}$ & $100 \%$ \\
\hline
\end{tabular}

As shown in Table 2, the most dominant type-specific pre-sequence is pre-offers and the least type that occurred is pre-invitation. These statements imply situations to be offered as shown in Example 3:

\section{Example 3: Pre-offers}

PUS1: Ako si Popoy Kapoy.

(S1C3L1)

(I am Popoy Kapoy) 
Ang hyperacidity, dili di ay kaya sa haplas haplas lang.

$(\mathrm{S} 1 \mathrm{C} 3 \mathrm{~L} 2)$

(The hyperacidity, cannot be cured by rubbing (cream) only

Maong ako, Kremil S. Dunay two (2) times acid stopping power. (S1C3L3)

(So me, Kremil S. With two (2) times acid stopping power.)

Deretso sa hinungdan sa kaaslum sulod sa tiyan.

(S1C3L4)

(directly to the cause of acidity in the stomache)

Ayo in five (5) minutes.

(S1C3L5)

PUS2: For stomach pain due to hyperacidity, take the relief and

effectively that works inside

(S1C3L6)

Take Kremil S.

(S1C3L7)

Aluminum hydroxide, magnesium hydroxide, semethicone is

the generic name of Kremil S.

(S1C3L8)

If symptoms persist, please consult your doctor.

(S1C3L9)

Example 3 is a medicine which illustrates that the product is being offered through announcing a symptom that the person felt which was hyperacidity: "Ako si Popoy Kapoy" (S1C3L1). "Ang hyperacidity, dili di ay kaya sa haplas haplas lang” (S1C3L2). Popoy Kapoy then offered the product Kremil S wherein he said: "Maong ako, Kremil S. Dunay two (2) times acid stopping power" (S1C3L3) which defines its use in having two time acid stopping power. The second interlocutor repeated what Popoy Kapoy stated about hyperacidity: "For stomach pain due to hyperacidity, take the relief and effectively that works inside" (S1C3L6) and also then offered the product: "Take Kremil S" (S1C3L7) after stating about the hyperacidity.

\section{Example 4: Pre-announcements}

PUS1: Kamot ni Perla

$(\mathrm{S} 2 \mathrm{C} 5 \mathrm{~L} 1)$

(the hands of Perla)

PUS2: Nagsugod na sa pahapyod paphyod lang sa among mga

tudlo ni Allan.

(S2C5L2)

(started already in massaging massaging only of our

fingers of Allan)

((Hagip kamay))

(S2C5L3)

((holding hands))

$(\mathrm{S} 2 \mathrm{C} 5 \mathrm{~L} 4)$

(then it becomes holding (hands)

((Haplos kamay))

(S2C5L5)

((massage hands))

Tapos, nakagunit na siya

(S2C5L6)

(then, he held (my hands)

((Hawak kamay))

$(\mathrm{S} 2 \mathrm{C} 5 \mathrm{~L} 7)$

((holding hands))

PUS1: Sobra ka humok sa kamot, dali sa coconut oil sa Perla

((so soft in our hands, come to the coconut oil of Perla))

Wa nay mas muhamis pa

(S2C5L9)

(no (soap) is smoother yet) 
Example 4 is a household product that illustrates the pre-announcement in PUS2 telling a story about her love story of Allan which focuses on the hand: "Nagsugod na sa pahapyod paphyod lang sa among mga tudlo ni Allan. (S2C5L2) ((Hagip kamay)) (S2C5L3) Tapos, nahimog haplos (S2C5L4) ((Haplos kamay)) (S2C5L5) Tapos, nakagunit na siya (S2C5L6) ((Hawak kamay)) (S2C5L7)". Since pre-announcement is also known as story-preface (Schegloff, 2007). PUS1 or the interlocutor then described the product about the smoothness of Perla's hands: "Sobra ka humok sa kamot, dali sa coconut oil sa Perla (S2C5L8) Wa nay mas muhamis pa (S2C5L9). The present study on pre-announcements contradicts with Swandayani's (2011) study on the pre-sequences and politeness strategies of making requests in the conversations between transgender to their guests. Pre-announcements were the least type-specific pre-sequences found in the conversation while pre-requests were the dominant ones because the data that Swandayani (2011) studied is a face to face interaction whereas the present research studied on radio commercials.

\section{Example 5: Pre-pres}

PUS1: Tay, May kapa kay wala kay puti nga buhok.

$(\mathrm{S} 1 \mathrm{C} 5 \mathrm{~L} 1)$

PUS2: At forty (40), daghan nakog puti nga buhok kay naliwat kos imong lolo nga sayong nagputi ang buhok.

PUS1: Huh?

Murag wa man lage nako nabantayan nga nagputi imong buhok tay.

PUS2: Tungod na anak kay nigamit kog Swallow Black 5.

Mao na ikaw, ayaw tuguti nga makit-an ang puti sa imong buhok kay baynte otso (28) ka pa baya.

Safe nang gamiton tungod kay way isog nga kemikal.

Ni-a o, gamita ni.

Tested and proven ko kana.

Example 5 is a beauty product that presents that PUS1 complimented PUS2's hair, "Tay, May kapa kay wala kay puti nga buhok." (S1C5L1), which initiates as a pre-pre because the statement projects a further pre-sequence that checked whether the listeners will be able to recognize the product, which is Swallow Black 5, to be talked about. PUS2 gave an answer that he is like his grandfather who had white hair: "At forty (40), daghan nakog puti nga buhok kay naliwat kos imong lolo nga sayong nagputi ang buhok." (S1C5L2) PUS1 then again initiated another utterance which will still lead in introducing the product: "Huh? (S1C5L3) Murag wa man lage nako nabantayan nga nagputi imong buhok tay. (S1C5L4)" The statement "Murag wa man lage nako nabantayan nga nagputi imong buhok tay" is also another type-specific pre-sequence which PUS2 will finally introduce the product Swallow Black 5: "Tungod na anak kay nigamit kog Swallow Black 5. " (S1C5L5).

Table 3 exhibits Yule's (1996) speech acts evident in the gathered Cebuano radio commercials. 
Table 3

Summary of the Type-Specific Pre-Sequences and Functions of Speech Acts $\mathrm{N}=21$

\begin{tabular}{lccccc}
\hline \multirow{2}{*}{$\begin{array}{c}\text { Functions of Speech } \\
\text { Acts }\end{array}$} & Pre-invitations & Pre-announcements & $\begin{array}{c}\text { Pre- } \\
\text { offers }\end{array}$ & $\begin{array}{c}\text { Pre- } \\
\text { Press }\end{array}$ & \% \\
\cline { 2 - 5 } & 1 & 3 & 5 & 1 & $50 \%$ \\
\hline Representatives & 0 & 2 & 1 & 2 & $25 \%$ \\
\hline Expressives & 1 & 0 & 1 & 0 & $10 \%$ \\
\hline Commissives & 0 & 0 & 2 & 0 & $10 \%$ \\
\hline Directives & 0 & 0 & 0 & 0 & $0 \%$ \\
\hline Declarations & & & & \\
\hline
\end{tabular}

The most dominant function is the Representative which accumulated the highest frequency of $50 \%$, followed by Expressives with $25 \%$. On the other hand, Commissives with $10 \%$ and Directives with $10 \%$ occurred least among the Cebuano health commercials while Declarations were not found. Representatives, with $50 \%$, prevailed over the other types. Most of the commercials reflected in the data were observed to retell or recall a story. This is a way of describing the quality of the product and claiming the effectual advantages of it in which representatives are acts that are used to describe what the speaker believes to be true or not such as to describe, to insist, to predict, and to claim (Yule, 1996).

Interestingly, representatives are composed of the two dominant type-specific presequences found in Table 3 which are pre-offers and pre-announcements. Pre-offers dominated on representatives because most commercials under this type-specific were drama. Thus, drama is parallel to representatives which affirm the positive effects of the commercials.

\section{Example 6: Representatives}

PUS1: Sa hair (0.2) dili hairlike

(S2C6L5) (in the hair (0.2) not hairlike)

(It's expensive to have salon treatment noh)

PUS1: conditioner ra ni Uy (this is only conditioner)

(S2C6L8)

PUS2: Ako pud pero nganong gamantika mantika man akong buhok (me too but why is my hair so oily oily)

As observed in example 6 which is an example of a personal hygiene product, Kim Chui as PUS1 and another person named Kim as PUS2 dramatized a scenario wherein they talked about something that focused on one's hair: 'PUS1: Sa hair (0.2) dili hairlike (S2C6L5); PUS2: Mahal tawn ang magpa-salon treatment noh (S2C6L6)' At first, PUS1 pre-offered the product in S2C6L7: "conditioner ra ni uy" (S2C6L7) then PUS1 insisted to use the product in S2C6L9: "Ako pud pero nganong gamantika mantika man akong buhok" (S2C6L8) Thus, the drama of the commercial reflected both on pre-offers and representatives. 


\section{Example 7: Expressives}

PUS1: Mga misis unsa inyong say sa mga bongga kaayong mapalit sa lima sa pisos?

(Mrs. What can you say about the lavish item you can buy from five pesos?

PUS2: Sa lima ka pisos?

(of five pesos?)

Makapalit nakog og usa ka takod sa sapatos.

$(\mathrm{S} 1 \mathrm{C} 15 \mathrm{~L} 3)$ (I can already buy shoes)

PUS1: Wala o tuo? ((laugh))

(left or right?) ((laugh))

PUS3: Sa lima ka pisos?

(of the five pesos?)

PUS 4: Mahimo nakong magpacomb og usa ka lugas na buhok. (I can (let someone) comb a single strand of my hair)

PUS1: Dili kaha na patay nga buhok? ((laugh)) (isn't it white hair?) ((laugh))

Mabuang ta ninyo oi! (we can get crazy with you) Nasayod ba mo nga naa moy mapalit nga Tide five pesos sachet? (Do you know that you can buy Tide sachet for five pesos?)

Example 7 is a pre-pre wherein PUS1, acts as the son, asked some mothers what they can buy in five pesos: "Mga misis unsa inyong say sa mga bongga kaayong mapalit sa lima sa pisos?" (S1C15L1) PUS2, acts as mother A, and PUS3, acts as mother B, answered that they can buy a heel in a shoe or a comb: PUS2: "Makapalit nakog og usa ka takod sa sapatos." (S1C15L3); PUS3: "Mahimo nakong magpacomb og usa ka lugas na buhok" (S1C15L6). It is an expressive at the same time because the way PUS1 delivered his message is a statement of joy and like: "Wala o tuo? ((laugh))" (S1C15L4). Then he happily introduced the good news that there was a cheap product that could help them in washing clothes: "Nasayod ba mo nga naa moy mapalit nga Tide five pesos

sachet?'(S1C15L9)

In sum representatives and expressives could be used as pre-announcement, pre-offers and pre-pres .

\section{Conclusion and Recommendations}

Based on the findings, these conclusions can be derived. The frequent occurrence of categories such as Drama and testimonials reflects the clients' and advertisers' persuasive device in promoting medicine/ food supplements and beauty/cosmetic/hygiene products because Drama imitates the life-scenarios of the target audience which helps in relating to the needs of the audience while testimonial gives credibility on the product being advertised through personal testimonies of the product-user which strengthens the benefits of the product. Part of the persuasion process that can easily get the listener's attention using presequences, pre-offers and pre-announcements are mostly utilized in Cebuano-Bisaya radio commercials since these are helpful with product recall. Representatives and Expressives are functions of speech acts that are reflected in getting the listener's attention, specifically with 
pre-offers and pre-announcements because these type-specific pre-sequences are anticipated by the advertisers to relate and communicate with the target audience's needs and language.

Based on the findings and conclusions, these are the following recommendations of the study:

First the Department of Languages and Literature, frameworks and major concepts on linguistics should be introduced to 3rd year students to maximize familiarity with certain linguistic concepts. Second, researchers can conduct studies on advertising discourse which will be a big help in expanding and improving the media outlet in selling products such as the radio stations that use English as their spoken language should be studied since their listeners are Second language learners. Thus, commercials may have similar linguistic features with Cebuano-Bisaya commercials. Lastly, study on radio commercials can also be used as a reference material for discourse analysis specifically on advertising discourse, pragmatics and bilingualism.

\section{Acknowledgements}

The researchers would like to thank the following who assisted, supported, guided, and strengthened us in the fulfillment of this research endeavor: Foremost, to the Almighty God for continuously giving us the strength, wisdom, and hope to face all the challenges encountered especially in the process of technical writing, Ph.D. and Joseleanor M. Magno, M.A., our thesis adviser and instructor, who believed in us and have guided us through the process of technical writing and whose values taught us to take our time and to enjoy every moment in doing the study; Christy Tan-Constantino, M.A., our panel member, whose expertise and helpful suggestions improved the research; The three radio stations, namely: 94.7 Energy FM, 97.1 MOR, and 93.9 I!FM, which participated and supported the study on radio commercials; Paulino C. Llido, who taught, guided and gave us the will to explore all necessary means of gathering sources; Cooren Francois who supported us in giving some sources that we needed especially in pre-sequences; Mr. Cesar \& Mrs. Alma Apalla and Mr. Rafael III \& Mrs. Jean San Juan, our parents, whose prayers, understanding, patience, support, especially their financial provision, were the keys that kept us strive hard in completing this study; Lastly, the Linguistics and Literature Major students who supported and encouraged us with their prayers and hopes to pursue this study.

\section{References}

Allan, D. (2006). Effects of popular music in advertising on attention and memory. Journal of

advertising research, 46. 4, 434-444. Retrieved from

http://eds.a.ebscohost.com/eds/pdfviewer/pdfviewer?sid=ca86bb0a-45a8-4ac0a4eb72ac56e918eb \%40sessionmgr4002 \&vid $=6 \&$ hid $=4110$.

Ariosa, M. C. (2011). Collocation and speech acts in green advertisements (Published master thesis). University of San Carlos, Cebu, Philippines.

Bernsten, S. G. (2002). Using conversation analysis to evaluate pre-sequences in invitation, offer and request dialogues in ESL textbooks (Master thesis, University of Illinois). Retrieved August 23, 2014, from http://files.eric.ed.gov/ fulltext/ED469206.pdf

Book, A. et al. (1996). The Radio and Television Commercial. Third Edition. NTC Business books. 
Dayag, D. (2008). The discourse of print advertising in the Philippines: Generic structures and

linguistic features. Proceedings of the 22nd Pacific Asia conference on language, information and computation.

Erhun \& Erhun (2002). The qualitative impact of broadcast media advertisement on the perception of medicines in Nigeria. Journal Of Consumer Behaviour [serial online]. September 2003;3(1):8-19. Available from: Business Source Complete, Ipswich, MA. Accessed August 23, 2014

Guga-Cotea, A. (2013). Speech acts in English advertisements. Analele Universitatii. Retrieved August 20, 2014, from http://connection.ebscohost.com.

Gupta, V. (2013). Ad. Jingles: Brand recall. SCMS journal of Indian management, 10.2, 78- 89. Retrieved August 20, 2014, from http://eds.a.ebscohost.com/eds/pdfviewer/ pdfviewer?sid=65477f0d-9ec0-46f4-92a6-41076e1a25e1\%40sessionmgr4003\&vi $\mathrm{d}=1 \&$ hid $=4110$.

KAS Democracy (2008). Philippines. Retrieved last October 16, 2014 from http://www.google.com.ph/url?sa=t\&rct=j\&q=\&esrc=s\&source=web\&cd=1 \&ved $=0$ CBsQFjAA\&url hitp $\% 3 \mathrm{~A} \% 2 \mathrm{~F} \% 2 \mathrm{Fwww.kas.de} \% 2 \mathrm{Fupload} \% 2 \mathrm{FPublikationen} \% 2 \mathrm{~F} 2008 \% 2 \mathrm{Fdr}$ p h i 11 i p p i n e s p d f \& e i = a f J B V P X w I 6 O x m A W d 3 Y K 4 Bw\&usg=AFQjCNFYeOfwDKg38FTSi2LQGt4IHLOUwQ\&sig2=tF0y2thOL5I_ dGK1RzP_Yw\&bvm=bv.77648437, d.dGY

Lerner, G. (ed.) (2004). Conversation analysis: Studies from the first generation, 125. Amsterdam/Philadelphia: John Benjamins Publishing Co.

Liddicoat, A. J. (2007). Adjacency pairs and preference organization. An introduction to conversation analysis (pp. 105-124). London: Continuum Publisher.

Liddicoat, A. J. (2007). Expanding sequences. An introduction to conversation analysis (pp. 125-143). London: Continuum Publisher.

Magsaysay, M.L. (1984). Descritptive analysis of advertising trends in jingles, advertising copy and visual technique in television commercials. UP Cebu.

Mcleish, R. (1994).Radio production.Third edition.Bath Press. Oxford.

NCH Software (2014). Retrieved on November 13, 2014 from http://www.nch.com.au/ scribe/index.html

Olsson, V. \& Larsson, A. (2005). Humor in Advertising. Lulea University of Technology. Retrieved August 20, 2014.

Ray, E. \& Donohew, L. (Eds.). (1990). Communication and health: systems and applications. 153, 155-159. New Jersey: Lawrence Erlbaum Associates, Inc., Publishers.

Saban, M. (2013). From healthy diet infographics to smokeless device stats.Retrieved last August 23, 2014 from http://www.trendhunter.com/slideshow/health conscious.

Schegloff, E. A. (2007). Sequence organization in interaction I: A primer in conversation analysis. Cambridge: Cambridge University Press.

Schegloff, E. A. (1988b). On an actual virtual servo-mechanism for guessing bad news: $A$ single-case conjecture. Social problems, 35, (4) 442-57.

Schmidt, R. and Kess, J. (n.y).Persuasive Language in Advertising and Televangelism. 
University of Victoria. Retrieved last December 28, 2014 from http://journals.uvic.ca/ index.php/WP LC/article/viewFile/5499/2107.

Sidnell, J. (2010). Sequence. Conversation analysis: An introduction (pp. 95-109). United Kingdom: A John Wiley \& Sons, Ltd., Publication.

Šliburytė, L \& Klimavičius, M. (2012). Humor appeal in advertising: How to use effectively. Economics and management, 17 (3), 1115-1124.

Shimp, T., Wood,S.,\&Smarandescu,L.(2007).Self-generatedadvertisements:Testimonials and the perils of consumer exaggeration. Journal of advertising research, 47(4), 453461. Retrieved fromhttp://eds.a.ebscohost.co/eds/pdfviewer/pdfviewer?sid=cbb335c9f21b-44e4-91c8- $\quad$ 444abbce769f\%40sessionmgr4003\&vid=1\&hid=4110.

Swandayani, A. I. (2011). A study on the pre-sequences and politeness strategies of making requests in the conversations between transgenders to their guests (Master thesis, Unika Soegijapranata, Indonesia). Retrieved on August 20, 2014 from http://eprints. unika.ac.id /491/

Tejal P., et al. (2013). Cosmetics and health: usage, perceptions and awareness. Bangladesh journal of medical science, 12, 393-394.

The Nielsen Company (2014). Retrieved October 15, 2014, from http://www.nielsen. com/us/en/solutions/measurement/ audience.htm

Thompson, E. \& Yeboah, A. (2013). Health information from elite to popular media: are Ghanaian media creating more space for health information/education? Critical Arts, 27(3), 370 \& 16. Retrieved last September 3, 2015 from

http://eds.a.ebscohost.com/eds/detail/detail?vid=6\&sid=251c4469-9a41-4a75-b8b2-61a4 106a5ee9\%40sessionmgr4004\&hid=4110\&bdata=JnNpdGU9ZWRzLWxpdm $\mathrm{U} \% 3 \mathrm{~d} \# \mathrm{db}=$ edsglr\&AN=ed sgcl.341557552.

Vilariño, M. (1996). The discourse of radio commercials and the function of persuasion. Some Sundry Wits Gathered Together, 197-204. Retrieved last January 3, 2015 from http://ruc.udc.es/bitstream/2183/9520/1/CC_26_art_17.pdf

Warner, C. (2009). Media selling: television, print, internet, radio.

Williams, H., et. al (2012). Hazard of household cleaning products: A study undertaken by the UK National Poisons Information Service. Clinical Toxicology (15563650), 50(8), 770-775. doi:10.3109/15563650.2012.709936

Yule, G. (1996). Pragmatics. Oxford: Oxford University press. 